\title{
DIFFERENTIAL IMPACT OF THE TEMPERATURE STRESS AND SOIL DROUGHT ON LIPOXYGENASE ACTIVITY IN WINTER RYE PLANTS
}

\author{
L. M. BABENKO, K. O. ROMANENKO ${ }^{\bowtie}$, I. V. KOSAKIVSKA \\ M.G. Kholodny Institute of Botany, National Academy of Sciences of Ukraine, Kyiv;

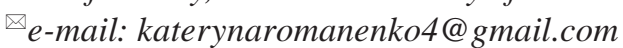

Received: 5 July 2021; Accepted: 12 November 2021

\begin{abstract}
Lipoxygenase cascade is a source of physiologically active compounds, the presence of which is considered not only as a sign of damage but also as a trigger of adaptive responses to stress. The aim of the study was to determine the effects of short-term $(2 \mathrm{~h})$ heat $\left(40^{\circ} \mathrm{C}\right)$ and cold $\left(4^{\circ} \mathrm{C}\right)$ temperature stress and moderate soil drought on lipoxygenase (LOX) activity in 14-day-old winter rye (Secale cereale L. 'Boguslavka') plants. The shoots were found to have both membrane-bound 9-LOX and 9-LOX and soluble 13-LOX activity, the roots - membrane-bound 9-LOX activity. After heat stress, the activity of 9-LOX and 9-LOX in the shoots increased by 3 and 2 times, respectively, the activity of 9-LOX in the roots - by 2 times, and 13-LOX activity in the shoots decreased by 1.5 times. After the cold stress, the activity of 9-LOX and 9-LOX in the shoots raised by almost 1.5 times, the activity of 9-LOX in the roots - by 1.2 times. Moderate soil drought caused enhancement in the activity of both membrane-bound isoforms of 9-LOX in the shoots by 1.5-2 times and in the roots - by 3 times. The established fluctuations indicate that molecular forms of LOX with different localization are differentially involved in the winter rye response to temperature stress and moderate soil drought.
\end{abstract}

Ke y wo rds: Secale cereale, lipoxygenase activity, hyperthermia, hypothermia, water deficit.

$\mathrm{E}$ xtreme temperatures and soil drought are among the most common abiotic stressors that adversely affect plant growth, development, and yield. According to the European Climate Assessment and Dataset, the number of extremely hot days in Europe has more than tripled in the last two decades, and during 1950-2018 the temperature in hot extremes increased by $2.3^{\circ} \mathrm{C}$. At the same time, the number of days with extremely low temperatures decreased 2-3 times [1].

To overcome stress, plants apply certain adaptive strategies, which include morphological, physiological, and biochemical responses, and predetermine growth success and productivity. Recent research has shed light on the formation of a stressresistance mechanism that combines the perception and transduction of external signals and the subsequent triggering of specific metabolic processes [2]. One of the negative effects of stress is a disturbance of the functional properties of cell membranes, their restructuring, which is to a large extent related to lipids [3].

Lipid signalling compounds include multifunctional oxylipins - products of the lipoxygenase (LOX) cascade of oxidation of polyunsaturated fatty acids (PUFA). Their occurrence is considered not only as a sign of damage but also as a trigger mechanism of adaptive response [4]. The products of LOX metabolism also include anti-stress hormones - traumatic and jasmonic acids, the biosynthesis of which is enhanced by stress-accumulated reactive oxygen species (ROS) [5]. Oxylipins have been identified in plants of different taxonomic groups. They are involved in the regulation of growth, development, the formation of responses to environmental signals, and the attack of pathogens $[4,6]$.

Oxylipins can be formed spontaneously and as a result of enzymatic reactions. Spontaneous formation occurs under optimal conditions and abiotic and biotic stresses. Moreover, the intensity 
of this process increases, especially in antioxidant deficiency [6]. Metabolism of oxylipins begins with the oxidation of PUFA with the formation of hydroperoxides affected by lipoxygenases. Lipoxygenases (linoleate: oxygen: oxidoreductase EC 1.13.11.12) catalyse the attachment of molecular oxygen at the sites of double bonds of the PUFA carbon chain and have the oxidation specificity of C-9 (9-LOX) or C-13 (13-LOX). Fatty acid hydroperoxides can be further utilized with the involvement of a number of enzymes resulting in the production of a significant amount of various oxylipins (jasmonates, traumatin, aldehydes, ketols, epoxyalcohols, divinyl ether, etc.) that have specific biological functions $[4,6]$.

Initial responses to temperature stresses and soil drought are associated with the activation of signalling systems and an increase in plant cells of intermediates involved in the transduction of abiotic signalling to the genome. One such intermediate is LOX [6]. The analysis of the literature showed that the research on abiotic stress influence on the enzymatic activity of LOX of cereals is fragmentary, and the results are not always unambiguous. The lipoxygenase molecular weight in seedlings of winter wheat Triticum aestivum L. was found to be $90 \mathrm{kDa}$ and the enzyme amino acid composition is characterized by a high content of glutamic acid, proline, valine, isoleucine, leucine, and low-histidine, tyrosine, phenylalanine, threonine, tryptophan, and cysteine. Changes in LOX activity depended on the resistance of the wheat genotype to Fusarium graminearum Schwabe. Salicylic acid induced an enhancement in enzyme activity [7]. Changes in LOX activity associated with endogenous ethylene synthesis and leaf blade detachment were observed in winter rye (Secale cereale L.) cv. 'Priekulu' plants. The maximum LOX activity was detected in young, fast-growing tissues of winter rye leaves and coincided with the high rate of ethylene production. Treatment of seedlings with ethylene synthesis stimulants ethephon and 1-aminocyclopropane-1carboxylic acid (ACC) led to some raise in LOX activity. A sharp increase in LOX activity after treatment with ethephon and ACC indicates that the enzyme is involved in a rapid metabolic response to changes in hormonal balance [8]. In durum wheat (Triticum durum Desf.), of the six LOX genes, only one TdLpx-A2E gene was overexpressed under osmotic and salt stresses that was accompanied by a significant enhancement in enzyme activity [9]. Three isoforms of lipoxygenases and their genes
LoxA, LoxB and LoxC [10] were identified in the germinal axes of barley Hordeum distichum $\mathrm{L}$. Isoforms, LOX-1 and LOX-2, the synthesis of which encodes the genes LoxA and $\operatorname{Lox} C$, are described in detail, whereas the LOX isoform encoded by the LoxB gene was not isolated [11]. Plants are characterized by a pronounced dependence on ambient temperature. 9-LOX and 13-LOX activity was identified in the mesocotyl of etiolated maize seedlings. Under short-term hypothermia, only 13-LOX activity was enhanced. It is suggested that the intensification of the 13-LOX pathway for oxylipin synthesis, aimed at forming the plant cell response at low temperatures, may be involved in the implementation of anti-stress programs [12]. Under drought stress, the activity of membrane-bound LOXs enhanced and the activity of soluble forms of LOX in the leaves of winter wheat declined. A relationship between LOX activity and drought resistance index was registered. Isoforms of the enzyme differentially involved in the adaptation of winter wheat to water deficit [13]. Under drought the transcription of $\mathrm{LOX}_{1}$ and $\mathrm{LOX}_{2}$ genes enhanced that led to increase of the corresponding mRNA levels, content, and activity of lipoxygenases. However, abscisic acid did not mediate an increase in LOX expression but caused a decrease in $\mathrm{LOX}_{2}$ activity and did not affect LOX $_{1}$ activity. Under the water deficit, LOX isoenzymes induced oxidative modification of membrane lipids by increasing the content of hydroperoxides through the esterification of lipid bilayer fatty acids [14].

Rye is one of the important cereals and ranks first among cereals in regions where wheat cultivation is difficult or impossible. It is the most cold-resistant of cereals, less demanding on soil fertility and humidity compared to wheat and barley. Unlike other cereals, rye can be grown without the use of herbicides and in most cases without fungicides that ensure an ecological harvest [15]. Since lipoxygenase compounds play an important role in the formation of adaptive responses our work aimed to identify lipoxygenases in winter rye (Secale cereale) plants and study the effect of abiotic stresses, including short-term hyper- and hypothermia and soil drought on their activity.

\section{Materials and Methods}

Plant material. Winter rye (Secale cereale L.), cv. 'Boguslavka' plants were studied. The genotype is medium-ripe, winter- and cold-resistant. The seeds were sterilized in $80 \%$ ethyl alcohol solution, 
washed with distilled water, and soaked for $3 \mathrm{~h}$. The seeds were germinated in a thermostat in cuvettes on water-soaked filter paper at $24^{\circ} \mathrm{C}$ for $21 \mathrm{~h}$. Peeled grains were planted in 2-liter containers. Calcined river sand was used as a substrate. Plants were grown under controlled conditions at a temperature of $20 / 17^{\circ} \mathrm{C}$ (day/night), light intensity $190 \mu \mathrm{mol} \mathrm{m}^{-2} \cdot \mathrm{s}$, photoperiod 16/8 h (day/night), relative humidity $65 \pm 5 \%$. The humidity of the substrate was maintained at $60 \%$ of the total moisture content. Watering was performed daily with Knop solution at the rate of $50 \mathrm{ml}$ per vessel.

Abiotic stress treatments and sample collection. To simulate stress, 14-day-old plants were exposed to the short-term $(2 \mathrm{~h})$ effect of temperatures of $40^{\circ} \mathrm{C}$ and $4^{\circ} \mathrm{C}$ at the specified mode of humidity and lighting. Soil drought was obtained by stopping watering of 14-day-old plants for four days until the leaves wither and halving the moisture content of the substrate. The second and third leaves were examined.

Isolation of lipoxygenase. To isolate LOX preparations, plant samples were homogenized in cooled to $4^{\circ} \mathrm{C} 0.1 \mathrm{M}$ phosphate buffer ( $\mathrm{pH}$ 6.3), which contained $2 \mathrm{mM}$ phenylmethylsulfonylfuoride, $0.04 \%$ sodium metabisulfate. Homogenate was centrifuged (K-24, Germany) at $4000 \mathrm{~g}$ for 30 $\min$ at $4^{\circ} \mathrm{C}$. The obtained supernatant was used to determine LOX activity. To construct curves of $\mathrm{pH}$-dependence of lipoxygenase oxidation standard rates of linoleic acid, $0.1 \mathrm{M}$ sodium-acetate $(\mathrm{pH}$ 4.05.5), $0.1 \mathrm{M}$ sodium-phosphate $(\mathrm{pH}$ 6.0-8.0) and borate $0.1 \mathrm{M}$ ( $\mathrm{pH} 8.0-9.5)$ buffer solutions were used. Linoleic acid concentrations in the $2.5 \mathrm{ml}$ reaction mixture were $40-100 \mu \mathrm{M}$, with or without $50 \mu \mathrm{M}$ of lubrole.

Determination of lipoxygenase activity. The 9- and 13-LOX activities were determined spectrophotometrically at $\lambda=234 \mathrm{~nm}$ using linoleic acid as substrate at $\mathrm{pH}$ 4.5-9.5 in the presence or absence of $50 \mu \mathrm{M}$ lubrole, respectively [12]. LOX activity was measured using the spectrophotometer Jenway UV-6850 (Great Britain). The reaction was initiated by adding 50-100 $\mu \mathrm{l}$ of enzyme solution (protein concentration of $0.5-1.0 \mathrm{mg} / \mathrm{ml}$ ) and at the constant temperature of $25 \pm 0.1^{\circ} \mathrm{C}$. The reaction was observed considering an increase in reaction mixture optical density at $\lambda=234 \mathrm{~nm}$ that corresponds to maximum absorption of conjugate diene chromophore in molecules of linoleic acid hydroperoxide whose molar extinction coefficient is $23000 \mathrm{M}^{-1} \mathrm{~cm}^{-1}$. Protein content was measured according to the method [16].

Statistical analysis. All measurements were performed with two biological and three analytical replicates. The results were statistically analysed using the One-way ANOVOA. Differences were considered significant at $P \leq 0.05,0.01$. The data shown in the figures are mean values \pm standard error (SE), $n=3$.

\section{Results and Discussion}

In the shoots of 14-day-old winter rye plants were identified membrane-bound forms of LOX: 9- $\mathrm{LOX}_{1}\left(\mathrm{pH}_{\mathrm{opt}} 6.0\right)$ and 9-LOX $\left(\mathrm{pH}_{\mathrm{opt}}\right.$ 6.5) and soluble 13- $\mathrm{LOX}\left(\mathrm{pH}_{\mathrm{opt}} 6.8\right)$, in the roots there was the membrane-bound form - 9-LOX ( $\mathrm{pH}_{\text {opt }}$ 6.2) (Fig. 1).

It was shown that differentiated changes in lipoxygenase activity took place under abiotic stresses. Thus, after short-term hyperthermia, the activity of membrane-bound LOX increased, and the activity of soluble LOX decreased. In the shoots, the 9-LOX 1 and 9-LOX 2 activities enhanced by three and two fold, respectively, in the roots twice. The maximum LOX activity was recorded for membrane-bound 9-LOX from the shoots. The activity of cytosolic 13-LOX, on the contrary, decreased by 1.5 fold and reached minimal level (Fig. 2). After short-term hypothermia the activity of 9-LOX ${ }_{1}$ and 9-LOX ${ }_{2}$ enhanced almost by 1.5 fold in the shoots, and by 1.2 fold in the roots. A slight increase in the activity of soluble 13-LOX in the shoots was observed. Under moderate soil drought conditions, the shoots of winter rye plants showed some rise in the activity of both membrane-bound isoforms of 9-LOX by 1.5 and 2 fold, and the activity of 9-LOX in the roots enhanced almost threefold. At the same time, in the shoots, there was a decrease in the activity of soluble 13-LOX.

Thus, non-specific response to abiotic stresses was an increase in the activity of membrane-bound 9-LOX ${ }_{1}$ and 9-LOX ${ }_{2}$ of the shoots and 9-LOX of rye roots. At the same time, specific traits were identified to respond to individual stresses. The activity of $\mathrm{LOX}_{1}$, localized in the shoots, was more sensitive to heat stress and $\mathrm{LOX}_{2}$ to cold stress, while the activity of 9-LOX in the roots was more sensitive to moderate soil drought. On the other hand, the response of soluble 13-LOX differed significantly. After heat and drought stresses, a decrease in enzyme activity was observed, and only after cold stress, there was a slight enhancement in LOX 


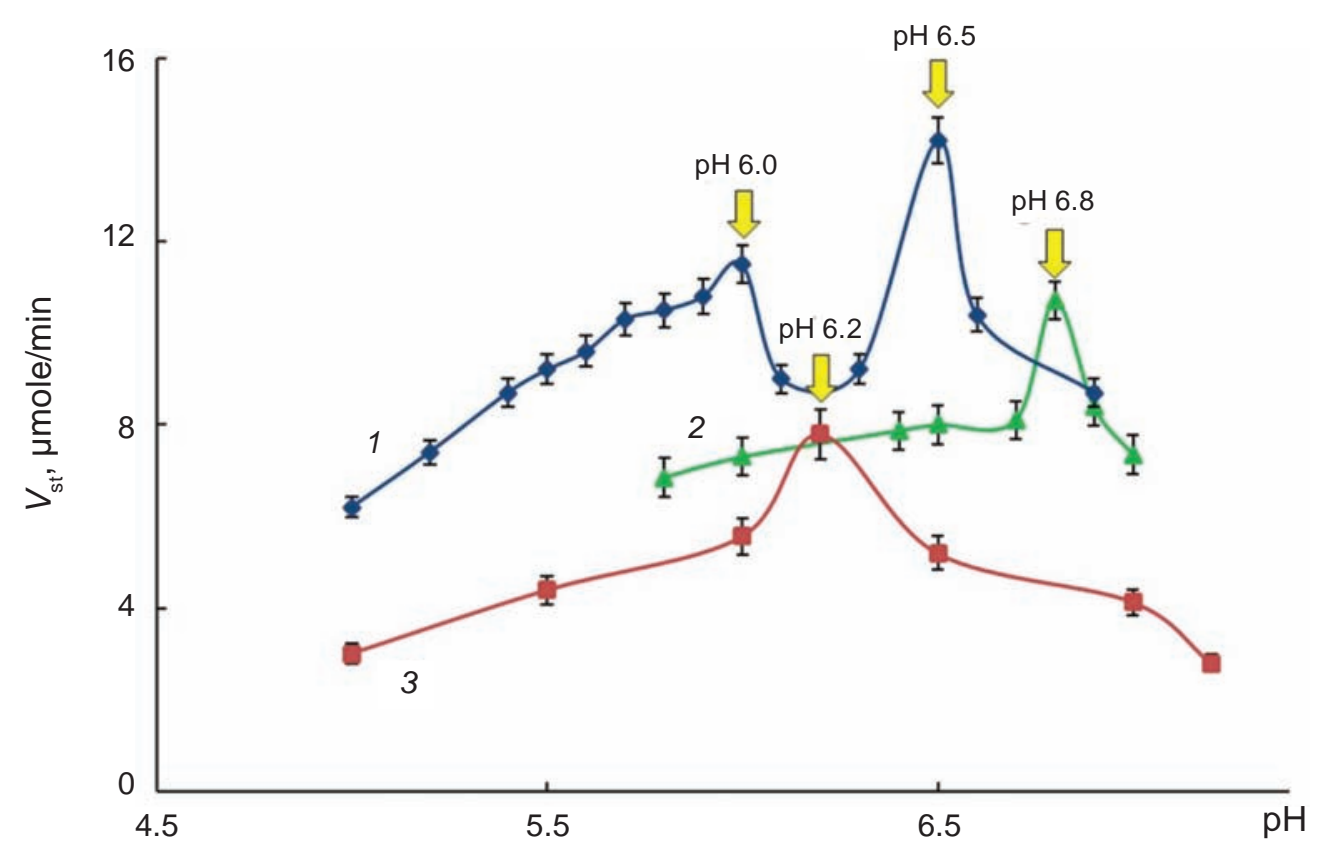

Fig. 1. Dependence of the stationary rate (Vst) of oxidation reaction of linoleic acid on pH of incubation environment in shoots $(1,2)$ and roots (3) of 14-day-old winter rye. 1 and 3-9-LOX, 2-13-LOX

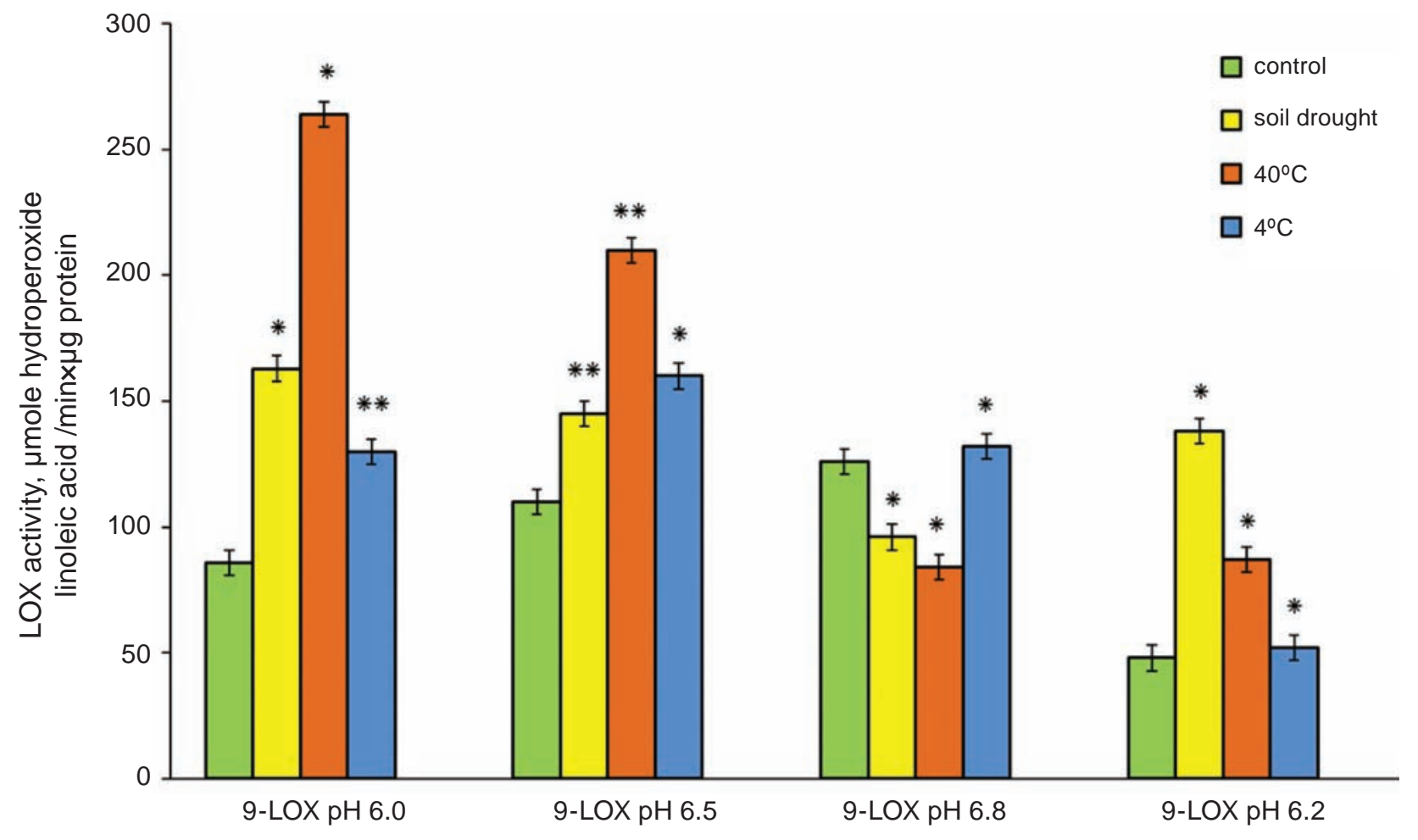

Fig. 2. Effects of abiotic stresses on lipoxygenase activity ( $\mu$ mole hydroperoxide linoleic acid $\mathrm{min}^{-1} \times \mu \mathrm{g}$ protein) in 14-day-old winter rye plants. Note. The activity 9-LOX1 ( $\left.\mathrm{pH}_{\text {opt }} 6.0\right), 9-\mathrm{LOX} 2\left(\mathrm{pH}_{\text {opt }} 6.5\right), 13-L O X\left(\mathrm{pH}_{\text {opt }} 6.8\right)$ in the shoots and 9-LOX $\left(\mathrm{pH}_{\text {opt }} 6.2\right)$ in the roots after short-term $(2 \mathrm{~h})$ heat $\left(40^{\circ} \mathrm{C}\right)$, cold $\left(4^{\circ} \mathrm{C}\right)$ temperature and moderate soil drought; asterisks denote significant differences between the parameters of the control and the experimental groups: $* P \leq 0.05 ; * * P \leq 0.01$ 
activity. So, our study revealed differential features in the change of lipoxygenase activity affected by abiotic stresses.

Numerous scientific studies indicate that the activity of LOX can be considered as a biological marker of the physiological state of the plant $[13,17]$. Plant lipoxygenases are localized mainly in vegetative tissues; however, they are also present in seeds, especially in legumes. Lipoxygenase isoforms are soluble proteins found in the stroma of chloroplasts, vacuoles, cytosols, mitochondria, and lipid bodies [4]. At the same time, LOX substrates are poorly soluble in an aqueous medium at physiological $\mathrm{pH}$ values. It is suggested that the activation of soluble LOX occurs due to the optional $\mathrm{Ca}^{2+}$-dependent association with cell membranes [18]. LOX activity is regulated by phosphorylation and release of LOX-PUFA substrate [19].

The functions of vegetative LOXs have been studied and characterized in detail, while the role of seed LOXs has been insufficiently investigated. Thus, five vegetative isoforms of LOX and four seed ones were identified in Glycine max Moench. Detailed comparative analysis of the crystal and conformational structure of vegetative and seed isoforms of the enzyme revealed important differences that explain various aspects of activity and positional specificity. It was found that the substrate of vegetative LOX is free PUFA (18:2 and 18:3), and the substrate of seed LOX triglycerides. Multiple LOX isoforms have unique biochemical properties and different cellular and tissue localization. Thus, vegetative soybean LOXs localized in the bean-specific paravenal mesophyll cell [18]. Plants are characterized by a pronounced dependence on ambient temperature. The effects of temperature on LOX activity were shown to depend on the heat resistance of plants, intensity, and duration of stress. Thus, LOX activity in the roots of Cucumis sativus L. sensitive to low positive temperatures did not change at low temperature, while in the cold-resistant pumpkin species Cucurbita ficifolia Bouché the activity of all LOX isoforms enhanced [20]. In cucumber fruits at low positive temperature LOX activity increased, and at temperature $37^{\circ} \mathrm{C}$ - decreased. It is suggested that the decrease in activity may be the result of thermal inactivation of the enzyme [21]. It is shown that after short-term cold stress the activity of LOX in seedlings of a heat-resistant variety of rape Brassica napus L. cv. 'Triangel' reduced by 34\%, while after short-term heat stress did not change. At the same time, the activity of LOX of the cold-resistant $\mathrm{cv}$. 'Milena' declined almost twice after short-term heat stress and did not change after short-term cold stress [22]. Information on the isoenzyme composition of cereals lipoxygenases is quite limited. Thus, molecular forms of LOX were identified in mature grains and that affects the content of spare proteins and the quality of gluten [23]. It was established that with increasing LOX activity, the content of carotenoids in wheat grain declined. The nutritional quality of bread and the level of antioxidants in it can be improved through the use of genotypes with low LOX activity in the grain [24]. Lipoxygenase with a molecular weight of $100 \mathrm{kDa}\left(\mathrm{LOX}_{100}\right)$ was identified in the leaves of winter wheat. After exogenous treatment of plants with methyl jasmonate, chitin oligosaccharides, and chitosan, its content increased. On the other hand, treatment of the rusty fungus Pgt (Puccinia graminis f. sp. tritici) ellicator reduced the amount of $\mathrm{LOX}_{100}$ and induced the emergence of two new isoforms of LOX [25]. A study of the leaf proteome of 8-day-old wheat plants revealed a higher level of LOX and jasmonate-induced proteins in drought conditions [26]. In our previous research, we showed that in the shoots of the 14-day-old spelt Triticum spelta cv. 'Frankenkorn' there are three molecular forms of 9-LOX: $\mathrm{LOX}_{1}\left(\mathrm{pH}_{\mathrm{opt}} 5.5\right), \mathrm{LOX}_{2}$ $\left(\mathrm{pH}_{\mathrm{opt}} 5.8\right)$, and $\mathrm{LOX}_{3}\left(\mathrm{pH}_{\mathrm{opt}}\right.$ 6.2) and one form of 9-LOX $\left(\mathrm{pH}_{\mathrm{opt}} 6.0\right)$ - in the roots. The activity of $\mathrm{LOX}_{1}$ and LOX $\mathrm{LO}_{2}$ of the shoots as well as the activity of 9-LOX of the roots, enhanced significantly after short-term hyperthermia [27]. Under moderate soil drought conditions, there was a substantial rise in the activity of $\mathrm{LOX}_{2}$ and $\mathrm{LOX}_{3}$ in shoots, while the increase in the activity of $\operatorname{LOX}_{1}$ was less pronounced. The highest increase in enzyme activity was recorded for 9-LOX, localized in the roots of spelt [28]. Changes in LOX activity under hyperthermia we observed along with ultrastructural rearrangements in mesophyll cells of $T$. spelta leaves. Thus, in the stroma of chloroplasts, there was partial destruction of thylakoid membranes, which was expressed in the wavy packing of thylakoids and significant expansion of lumenal gaps and accumulation of plastoglobules. The number of lipid droplets increased in the cytoplasm [29]. Lipid-like substances (carotenoids, tocopherol, plastoquinone) and specific proteins with enzymatic and structural functions were observed to be deposited in plastoglobules [30, 31]. Similar data we obtained with frost-resistant $T$. aestivum cv. 
'Volodarka'. Thus, during short-term hyperthermia $\left(40^{\circ} \mathrm{C}, 2 \mathrm{~h}\right)$, a higher activity of membrane-bound LOX $\left(\mathrm{pH}_{\text {opt }} 7.0\right)$ and $\mathrm{LOX}\left(\mathrm{pH}_{\mathrm{opt}} 6.0\right)$ occurred in the shoots of 14-day-old plants, as well as LOX $\left(\mathrm{pH}_{\mathrm{opt}} 6.5\right)$ in roots. The number of lipid droplets in the cytoplasm of mesophilic cells increased [17].

The results of our study on winter rye plants agree with previously obtained data on other crops. Differential changes in lipoxygenase activity after temperature stress and drought (Fig. 2) indicate that different forms of the enzyme are involved in different ways in the regulation of metabolic response to stress. After short-term hyperthermia, the activity of membrane-bound LOX increased, while the activity of soluble LOX decreased. The LOX-1 activity localized in the shoots was more sensitive to heat stress, and LOX-2, to cold stress, while the 9-LOX activity in the roots was more sensitive to soil drought. The activity of soluble 13LOX differed significantly from membrane-bound 9-LOX. After heat stress and drought, a decrease in 13-LOX activity was observed, and only after cold stress was a slight increase in 13-LOX activity observed.

The publication of recent years reported that in genome of Brassica rapa were identified thirteen divergent lipoxygenase genes. However, the expression of only two of them - BraA.LOX5 and BraA.LOX2 was improved under drought and high-temperature conditions. Under heat stress, BraA.LOX5 expression rose by 6.16 fold, while BraA.LOX2 expression increased by 15.76 and 18.67 fold, respectively, under drought and combined stress. The expression of these genes was positively correlated with accumulation of the main biochemical stress indicator - malondialdehyde (MDA) [32]. Early activation of $M t L O X 1$ specific lipoxygenase gene expression occurred in the roots of the drought-resistant chickpea genotype Cicer arietinum L., which was accompanied by the accumulation of oxylipins [33].

The synthesis of signal compounds involved in the formation of plant adaptation strategy is one of the key physiological functions of lipoxygenases. Changes in the lipoxygenase activity take place during ontogenesis and in response to external and internal stimuli and are regulated at the transcriptional, translational, and posttranslational levels $[4,6]$. Phytohormones are involved in the regulation of LOX activity. Thus, in leaves of Solanum tuberosum L. endogenous ABA activated the 9-LOX gene, while the effect on the activity of the 13-LOX gene was less pronounced. However, lipoxygenase gene expression was not observed during exogenous hormone treatment. In Solanum lycopersicum exogenous ABA enhanced the expression of the gene encoding 9-LOX synthesis [34]. Studies conducted on the leaves of Brassica rapa have demonstrated that $\mathrm{ABA}$ is the main regulatory element of LOX gene expression under heat stress. Under heat stress, overexpression of ABA-regulated BraA.LOX5. a was found coding for cytoplasmic LOX protein whereas, under drought and combined stress, the major gene was methyl jasmonate-regulated BraA.LOX2.a coding for chloroplast LOX protein suggesting the differential role of LOX [32].

Conclusion. The results of our study on winter rye plants, together with previously obtained data on winter wheat and spelt genotypes, allow us to conclude that vegetative lipoxygenases are involved in the formation of the response to abiotic stresses. The revealed changes in the lipoxygenase activity showed that molecular forms of lipoxygenase, which have different localization, are differentially involved in the adaptation of rye to stress temperatures and soil drought.

Conflict of interest. Authors have completed the Unified Conflicts of Interest form at http://ukrbiochemjournal.org/wp-content/uploads/2018/12/ coi_disclosure.pdf and declare no conflict of interest.

Funding. The publication contains the results of research conducted within the project funded by the National Academy of Sciences of Ukraine No III-82-17.463 "Hormonal regulation of growth and development of cereals under the influence of negative climatic factors” (2019-2023). The seeds of Secale cereale L. 'Boguslavka' were obtained from the collection of Institute of Plant Physiology and Genetics NAS of Ukraine. 


\section{ВПЛИВ ТЕМПЕРАТУРНИХ СТРЕСІВ ТА ГРУНТОВОЇ ПОСУХИ НА ЛІПОКСИГЕНАЗНУ АКТИВНІСТЬ ОЗИМОГО ЖИТА}

\author{
Л. М. Бабенко, К. О. Романенко ${ }^{\bowtie}$ \\ I. В. Косаківська \\ Інститут ботаніки ім. М.Г.Холодного \\ НАН України, Київ; \\ 凶e-mail: katerynaromanenko4@gmail.com
}

Ліпоксигенази (ЛОГ) - джерело фізіологічно активних сполук, наявність яких розглядається не лише як ознака пошкодження, але і як пусковий механізм формування адаптивних реакцій на стрес. Метою дослідження було вивчення впливу короткотривалих (2 год) теплового $\left(40^{\circ} \mathrm{C}\right)$ і холодового $\left(4^{\circ} \mathrm{C}\right)$ температурних стресів та помірної грунтової посухи на активність ліпоксигеназ 14-добових рослин озимого жита. Встановлено, що у надземній частині локалізовано мембранозв'язані форми ЛОГ: 9-ЛОГ та 9-ЛОГ 2 та розчинна форма 13-ЛОГ, тоді як у коренях - зв'язана з мембраною 9-ЛОГ. Після теплового стресу активність 9-ЛОГ 1 та 9-ЛОГ 2 у надземній частині зросла відповідно у 3 та 2 рази, активність 9-ЛОГ у коренях - вдвічі. Активність 13-ЛОГ у надземній частині зменшилась у 1,5 раза. Після холодового стресу активність 9-ЛОГ та 9-ЛОГ 2 у надземній частині зросла майже у 1,5 раза, активність 9-ЛОГ у коренях - у 1,2 раза. Після грунтової посухи у надземній частині спостерігали певний ріст активності обох мембранозв'язаних форм 9-ЛОГ (у 1,5-2 раза) та майже втричі збільшення активності цього ензиму в коренях. Дійшли висновку, що молекулярні форми ЛОГ з різною локалізацією, не однаково задіяні в адаптації озимого жита до стресових температур та помірної грунтової посухи.

Ключові слова: Secale cereale, ліпоксигеназна активність, гіпертермія, гіпотермія, грунтова посуха.

\section{References}

1. Lorenz R, Stalhandske Z, Fischer EM. Detection of a climate change signal in extreme heat, heat stress, and cold in Europe from observations. Geophys Res Lett. 2019; 46(14): 8363-8374.

2. Janni M, Gullì M, Maestri E, Marmiroli M, Valliyodan B, Nguyen HT, Marmiroli N. Molecular and genetic bases of heat stress responses in crop plants and breeding for increased resilience and productivity. J Exp Bot. 2020; 71(13): 3780-3802.

3. Islam Z, Paul K, Bhattacharjee S. Lipid chemistry in stress tolerance of plants. Food Sci Rep. 2020; 1(12): 22-27.

4. Babenko LM, Shcherbatiuk MM, Skaterna TD, Kosakivska IV. Lipoxygenases and their metabolites in formation of plant stress tolerance. Ukr Biochem J. 2017; 89(1): 5-21.

5. Kolupaev YE, Yastreb TO. Jasmonate Signaling and Plant Adaptation to Abiotic Stressors (Review). Appl Biochem Microbiol. 2021; 57: 1-19.

6. Savchenko TV, Zastrijnaja OM, Klimov VV. Oxylipins and plant abiotic stress resistance. Biochemistry (Mosc). 2014; 79(4): 362-375.

7. Molodchenkova OO, Adamovskaya VG, Ciselskaya LY, Bezkrovnaya LYa, Kartuzova TV, Iablonska VB. Purification and properties of lipoxygenase from wheat seedlings infected by Fusarium graminearum and treated by salicylic acid. Ukr Biochem J. 2016; 88(6): 26-34.

8. Ievinsh G. Soluble lipoxygenase activity in rye seedlings as related to endogenous and exogenous ethylene and wounding. Plant Sci. 1992; 82(2): 155-159.

9. Menga V, Trono D. The Molecular and Functional Characterization of the Durum Wheat Lipoxygenase TdLOX2 Suggests Its Role in Hyperosmotic Stress Response. Plants (Basel). 2020; 9(9): 1233.

10. Holtman WL, Van Duijn G, Sedee NJA, Douma AC. Differential Expression of Lipoxygenase Isoenzymes in Embryos of Germinating Barley. Plant Physiol. 1996; 111(2): 569-576.

11. Van Mechelen JR, Schuurink RC, Smits M, Graner A, Douma AC, Sedee NJ, Schmitt NF, Valk BE. Molecular characterization of two lipoxygenases from barley. Plant Mol Biol. 1999; 39(6): 1283-1298.

12. Kopich VN, Kretynin SV, Kharchenko OV, Litvinovskaya RP, Chashina NM, Khripach VA. Effect of 24-epibrassinolide on lipoxygenase activity in maize seedlings under cold stress. Biopolym Cell. 2010; 26(3): 218-224.

13. Permyakova MD, Permyakov AV, Osipova SV, Pshenichnikova TA, Shishparenok AA, Rudikovskaya EG, Rudikovsky AV, Verkhoturov VV, Börner A. Chromosome 
regions associated with the activity of lipoxygenase in the genome $\mathrm{D}$ of Triticum aestivum L. under water deficit. Russ $J$ Plant Physiol. 2017; 64(1): 28-40.

14. Maccarrone $\mathrm{M}$, Veldink GA, Agrò AF, Vliegenthart JF. Modulation of soybean lipoxygenase expression and membrane oxidation by water deficit. FEBS Lett. 1995; 371(3): 223-226.

15. Arendt EK, Zannini E. Cereal Grains for the Food and Beverage Industries. Cambridge, United Kingdom, Elsevier Science \& Technology, 2013. P. 220-243.

16. Bradford MM. A rapid and sensitive method for the quantitation of microgram quantities of protein utilizing the principle of protein-dye binding. Anal Biochem. 1976; 72(1-2): 248-254.

17. Babenko LM, Kosakivska IV, Akimov YuA, Klymchuk DO, Skaternya TD. Effect of temperature stresses on pigment spectrum, lipoxygenase activity and cell ultrastructure of winter wheat seedlings. Genet Plant Physiol. 2014; 4(1-2): 117-125.

18. Youn B, GE Sellhorn, RJ Mirchel, BJ Gaffney, Grimes HD, Kang C. Crystal structures of vegetative soybean lipoxygenase VLX-B and VLX-D, and comparisons with seed isoforms LOX-1 and LOX-3. Proteins. 2006; 65(4): 10081020.

19. Thivierge K, Prado A, Driscoll BT, Bonneil E, Thibault P, Bede JC. Caterpillar- and salivaryspecific modification of plant proteins. $J$ Proteome Res. 2010; 9(11): 5887-5895.

20. Lee SH, Ahn SJ, Im YJ, Cho K, Chung GC, Cho BH, Han O. Differential impact of low temperature on fatty acid unsaturation and lipoxygenase activity in figleaf gourd and cucumber roots. Biochem Biophys Res Commun. 2005; 330(4): 1194-1198.

21. Mao L, Pang H, Wang G, Zhu C. Phospholipase $\mathrm{D}$ and lipoxygenase activity of cucumber fruit in response to chilling stress. Postharvest Biol Technol. 2007; 44(1): 42-47.

22. Kosakivska IV, Babenko LM, Ustinova AY, Skaterna TD, Demirevska K. The influence of temperature conditions on lipoxygenase activity in seedling of rape Brassica napus var. Oleifera. Dopov Nac Akad nauk Ukr. 2012; (6): 134-137. (In Ukrainian).

23. Osipova SV, Permyakova MD, Pshenichnikova TA, Ermakova MF. Lipoxygenase and glutathione-dependent protein disulfide oxydoreductase activity in grains of intervarietal subsitution lines of common wheat with different gluten quality. Fiziol Biokh Kult Rast. 2011; 43: 446-452. (In Russian).

24. Leenhardt F, Lyan B, Rock E, Boussard A, Potus J, Chanliaud E, Remesy C. Wheat lipoxygenase activity induces greater loss of carotenoids than vitamin E during breadmaking. J Agric Food Chem. 2006; 54(5): 1710-1715.

25. Bohland C, Balkenhohl T, Loers G, Feussner I, Grambow HJ. Differential Induction of Lipoxygenase Isoforms in Wheat upon Treatment with Rust Fungus Elicitor, Chitin Oligosaccharides, Chitosan, and Methyl Jasmonate. Plant Physiol. 1997; 114(2): 679-685.

26. Zhang HM, Zhang LS, Lv H, Yu ZY, Zhang DP, Zhu WN. Identification of changes in Triticum aestivum L. leaf proteome in response to drought stress by 2D-PAGE and MALDI-TOF/TOF mass spectrometry. Acta Physiol Plant. 2014; 36(6): 1385-1398.

27. Babenko LM. Influence of stress temperatures on lipoxygenase activity in Triticum spelta. Bull Kharkiv Nat Agrar Univ. Ser Biology. 2018; 1(43): 40-45. (In Russian).

28. Babenko LM, Kosakivska IV. Effect of modeled soil drought on lipoxygenase activity in Triticum spelta. Dopov Nac Akad nauk Ukr. 2018; (8): 98104. (In Russian).

29. Babenko LM. Vodka MV, Akimov YuN, Smirnov AE, Babenko AV, Kosakovskaya IV. Specific features of the ultrastructure and biochemical composition of Triticum spelta L. leaf mesophile cells in the initial period of stress temperature action. Cell Tissue Biol. 2019; 13(1): 70-78.

30. Austin JR 2nd, Frost E, Vidi PA, Kessler F, Staehelin LA. Plastoglobules are lipoprotein subcompartments of the chloroplast that are permanently coupled to thylakoid membranes and contain biosynthetic enzymes. Plant Cell. 2006; 18(7): 1693-1703.

31. Vidi PA, Kanwischer M, Baginsky S, Austin JR, Csucs G, Dörmann P, Kessler F, Bréhélin C. Tocopherol cyclase (VTE1) localization and vitamin $\mathrm{E}$ accumulation in chloroplast plastoglobule lipoprotein particles. J Biol Chem. 2006; 281(16): 11225-11234.

32. Rai AN, Mandliya T, Kulkarni P, Rao M, Suprasanna P. Evolution and transcriptional 
modulation of lipoxygenase genes under heat, drought, and combined stress in Brassica rapa. Plant Mol Biol Res. 2020; 39(1): 60-71.

33. De Domenico S, Bonsegna S, Horres R, Pastor V, Taurino M, Poltronieri P, Imtiaz M, Kahl G, Flors V, Winter P, Santino A. Transcriptomic analysis of oxylipin biosynthesis genes and chemical profiling reveal an early induction of jasmonates in chickpea roots under drought stress. Plant Physiol Biochem. 2012; 61: 115-122.

34. Peña-Cortés H, Fisahn J, Willmitzer L. Signals involved in wound-induced proteinase inhibitor II gene expression in tomato and potato plants. Proc Natl Acad Sci USA. 1995; 92(10): 41064113. 